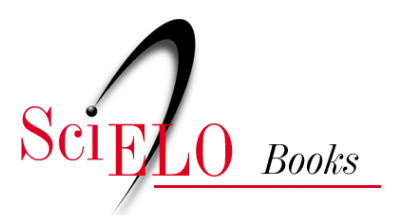

\title{
Estrada de Ferro SP-RS
}

\author{
José Carlos Radin \\ Gentil Corazza
}

\section{SciELO Books / SciELO Livros / SciELO Libros}

RADIN, J.C., and CORAZZA, G. Estrada de Ferro SP-RS. In: Dicionário histórico-social do Oeste catarinense [online]. Chapecó: Editora UFFS, 2018, pp. 56-59. ISBN: 978-85-64905-65-8.

https://doi.org/10.7476/9788564905658.0013.

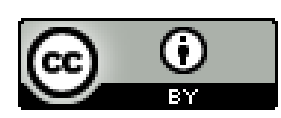

All the contents of this work, except where otherwise noted, is licensed under a Creative Commons Attribution 4.0 International license.

Todo o conteúdo deste trabalho, exceto quando houver ressalva, é publicado sob a licença Creative Commons Atribição 4.0.

Todo el contenido de esta obra, excepto donde se indique lo contrario, está bajo licencia de la licencia $\underline{\text { Creative Commons }}$ $\underline{\text { Reconocimento 4.0. }}$. 


\section{Estrada de Ferro SP-RS}

A Estrada de Ferro São Paulo-Rio Grande do Sul (EFSPRS) interligou a região Sul com a região Sudeste do Brasil. Foi projetada pelo engenheiro João Teixeira Soares, ainda em 1887, com um percurso de 1.403 $\mathrm{km}$, entre a cidade de Itararé, em SP, e a cidade de Santa Maria, no Rio Grande do Sul, permitindo uma conexão das malhas ferroviárias do Brasil, Uruguai e Argentina. Ela foi construída por etapas, em diferentes períodos. O trecho desta ferrovia, entre os rios Iguaçu e Uruguai, na cidade gaúcha de Marcelino Ramos, numa extensão de 347 $\mathrm{km}$, passando pelo Meio-Oeste catarinense, foi inaugurado em 1910. De alguma forma a ferrovia representou o novo "caminho das tropas", através do qual os campos gaúchos abasteciam os mercados paulistas e mineiros com gado e mulas, mas seus objetivos eram muito mais amplos do que o transporte de animais. Com a construção da EFSPRS, o Oeste catarinense inaugurava uma nova fase de sua história, inserindo-se na economia nacional e nos circuitos econômicos internacionais.

A EFSPRS resultou de um conjunto de fatores internos e externos, como o interesse do capital internacional, as necessidades regionais e a vontade política do Governo Federal. Do ponto de vista externo, o final do século XIX era um período de expansão do capitalismo mundial, com exportações de capital e tecnologia e conquista de novos mercados, processo associado à Segunda Revolução Industrial e à formação das grandes corporações multinacionais. Do ponto de vista interno, além do motivo estratégico de ocupação de um território de fronteira, a ferrovia servia ao propósito de fortalecer integração de toda a região sul à economia nacional, pois na passagem do Império à República o Brasil ainda era um país fragmentado, com muitos conflitos regionais, carente de investimentos externos, especialmente para desenvolver sua infraestrutura e fortalecer o mercado interno. Assim, pode-se dizer que no Oeste catarinense o capitalismo chegou de trem, no início do século XX, com todas as suas consequências, em termos de desenvolvimento capitalista, cortando distâncias, aproximando cidades, unindo mercados, despertando sonhos e ilusões, mas também 
com todas suas contradições e conflitos, esmagando vidas humanas sob seus dormentes, bem como destruindo valores e identidades das populações nativas. Foi assim, na Europa e nos Estados Unidos. Foi assim, também, no Oeste catarinense.

Embora as negociações efetivas para a construção desta ferrovia só tenham acontecido após a incorporação do território do Oeste catarinense ao território brasileiro, em 1895, sua história começa um pouco antes, em novembro de 1889 , às vésperas da proclamação da República, quando Dom Pedro II outorgou a concessão da ferrovia a João Teixeira Soares, possuidor de extraordinária visão estratégica e experiência nesse ramo. Credenciais não faltavam a este engenheiro, empresário, financista e proprietário de terras, pois antes já havia construído o difícil trecho que vai de Curitiba a Paranaguá. Logo após receber a concessão, ainda em 1890, Teixeira Soares criou a Compagnie Chemins de Fer Sud Ouest Brésilien, com capitais belgas e franceses, visando captar recursos para a construção da ferrovia que integraria essa parte do território catarinense à economia nacional e internacional.

Os trabalhos de construção da EFSPRS iniciaram em 15 de novembro de 1895 e o primeiro trecho, de $228 \mathrm{~km}$, foi inaugurado em 16 de dezembro de 1899. Em abril de 1904, a ferrovia chegou às margens do Rio Iguaçu, na divisa com Santa Catarina. Nesse momento, estava em operação todo o trecho paranaense, além do gaúcho, entre o Rio Uruguai e Santa Maria, faltando concluir apenas o trecho catarinense, entre os rios Iguaçu e Uruguai, para o qual foram recrutados muitos operários na própria região e em algumas cidades brasileiras. Muitos outros operários especializados também vieram do exterior. Estima-se que no auge da construção o contingente de mão de obra possa ter atingido o montante de 8.000 trabalhadores. A estrada foi construída na base da picareta, a um ritmo alucinante de 516 metros por dia. A inauguração final da obra só veio a ocorrer em 17 de dezembro de 1910.

Em 1908, a EFSPRS, que passava por dificuldades financeiras, foi vendida para o poderoso grupo norte-americano de Percival Farquhar, dono da Brazil Railway Company. Farquhar já havia construído a estrada de ferro Madeira-Mamoré e chegou a controlar quase metade da malha ferroviária nacional. O Grupo Farquhar era um 
conglomerado de empresas de diversos ramos espalhados por vários países. Percival Farquhar era engenheiro, financista e deputado nos Estados Unidos. Foi quando vendia máquinas agrícolas com seu pai para países da América do Sul que percebeu as grandes oportunidades de investimentos lucrativos, expandindo seus negócios para os países da América Central e do Sul, em Cuba, na Argentina, no Uruguai e na Bolívia. Seus negócios se estendiam a vários outros ramos, como eletricidade, gás, portos e companhias de navegação. Com suas empresas de navegação controlava os portos de Belém, Rio de Janeiro, Rio Grande e Paranaguá. Percival Farquhar sonhava com a construção de um império, que envolvia o controle dos transportes na América Meridional, abrangendo Argentina, Uruguai, Paraguai e Brasil.

No Oeste catarinense, além da ferrovia, o Grupo Farquhar operava também com a Southern Brazil Lumber \& Colonization Company, com a finalidade de explorar a madeira e colonizar a faixa de terras e matas de 15 quilômetros de cada lado dos trilhos, que recebeu como parte do pagamento pela construção da ferrovia.

A EFSPRS contribuiu enormemente para as atividades madeireiras e, além disso, foi considerada ferrovia colonizadora. A própria colonização do Oeste catarinense confunde-se em grande parte com o avanço da história da ferrovia. Além disso, a construção da ferrovia São Paulo-Rio Grande tem relação direta com a Guerra do Contestado, pois a nova realidade criada pela operação da ferrovia afetou fortemente o modo de vida das pessoas que residiam em sua área de abrangência, gerando descontentamento entre os sertanejos.

A EFSPRS foi, sem dúvida, a maior obra do início do século XX no Oeste catarinense, pois além de seu papel estratégico-militar de defesa territorial, ela desempenhou um papel econômico fundamental, contribuindo para o avanço da colonização e o desenvolvimento da indústria ervateira e madeireira, facilitou o transporte de mercadorias, as ligações entre cidades e a integração da região ao território brasileiro e à economia nacional. Em torno das estações do trem formaram-se núcleos urbanos e atividades econômicas variadas, irradiando o processo de mudança e desenvolvimento da região. 
O Império Farquhar desmoronou com a Primeira Guerra Mundial. Afetada por dificuldades financeiras, a EFSPRS foi encampada pelo Governo Federal, na década de 1940 e, depois, em 1996, foi novamente devolvida à iniciativa privada, no contexto das privatizações do governo Fernando Henrique Cardoso.

\section{REFERÊNCIAS}

ESPIG, Márcia J. Personagens do Contestado: os turmeiros da Estrada de Ferro São Paulo-Rio Grande do Sul (1908-1915). Pelotas: UFPEL, 2011.

GOULARTI FILHO, Alcides. A Estrada de Ferro São Paulo-Rio Grande na formação econômica regional em Santa Catarina. Florianópolis, Geosul, V. 24, N. 48, 2009. NODARI, Renato. Estrada de ferro São Paulo-Rio Grande: causas e consequências de sua construção em território catarinense (1900-1940). (Dissertação). Porto Alegre: UFRGS, 1999. 